\title{
FURTHER STUDIES OF THE EFFECTS OF SMOKE FROM TOWNS UPON VEGETATION IN THE SURROUNDING AREAS.
}

\author{
By CHARLes CROWTHER, M.A., Ph.D., \\ AND DAN. W. STEUART, B.Sc. \\ (Department of Agriculture, The University, Leeds.)
}

Is two previous communications a summary has been given of the results obtained in determinations of the relative degree of atmospheric pollution, firstly in various parts of the city of Leeds ${ }^{1}$, and secondly in the surrounding semi-urban and rural areas, to a distance in some directions of seven miles from the centre of the city ${ }^{2}$. The results obtained in the latter series indicated clearly the presence of extensive atmospheric pollution, showing the characteristics of coal smoke, in all parts of the area investigated. The degree of pollution was found to fall rapidly on passing in a northerly direction from the centre of the city into an area free from smoke-producing industries, but less rapidly on passing into similar areas to the north-east and east of the city, owing to the greater dispersion of the city smole in these directions by the prevailing winds. On the opposite side of the city, from northwest round by south to south-east, smoke pollution was found to be very high in all quarters.

On the completion of this preliminary diagnosis it was decided to attempt to measure directly the effects of the atmospheric pollution upon crops grown on agricultural land in various parts of the area investigated. The method proposed was to grow the same crops at each station in the same soil placed there for the purpose, and to compare the weight and composition of the crops obtained.

Similar experiments upon the same lines, but upon a smaller scale, were already in progress within the city ${ }^{3}$ and the prcliminary results

\footnotetext{
1 Crowther and Ruston. This Journal, Iv. 25.

3 Crowther and Stenart. This Journal, v. 391

"Crowther and Ruston. 'This vol, p. 387.
} 
obtained seemed to indicate that we might reasonably expect to get measurable differences in the yield of crops.

Accordingly seven experimental stations were selected, six being situated on the cleaner side of Leeds and the seventh, to give a marked contrast, on the more polluted side. The six cleaner stations were situated in pairs to the north, north-east and east of the centre of the city, there being in each direction a station at four miles and a second at seven miles from the centre. The seventh station was situated four miles out to the south-west, in the middle of a farm, with the nearest large source of smoke about a mile away. This station was about a mile distant from the one in this district at which samples of rain had been previously collected for twelve months ${ }^{1}$, so that it was deemed advisable to remove the rain-collecting outfit to the site of the vegetation tests and continue the collection of samples there for a further 12 months (July 1, 1912June 30,1913$)$. For purposes of comparison the collection was also continued for the same period at station E $7^{2}$ (Garforth)-this being selected as the most convenient. The sulphur-content of the 12 months' rainfall, expressed as pounds of $\mathrm{SO}_{3}$ per acre, is set out below, along with the corresponding totals obtained during the preceding 12 months:

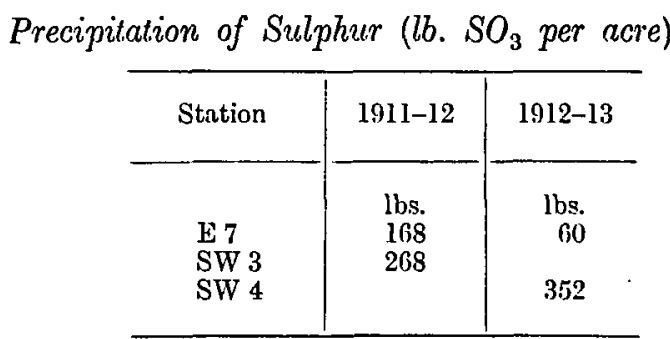

The marked reduction in the Garforth (E 7) total was probably attributable to the great difference in character of the two periodsthe earlier being notoriously wet, whilst the later included many prolonged spells of drought. It is all the more striking therefore to find on the other side an actual increase over the previous year's record, so that there could be no doubt as to the high degree of pollution of the atmosphere over this area. In view of the close network of industrial towns with which this part of the West Riding is covered it is indeed inevitable that such should be the case.

1 Crowther and Steuart, loc. cit. p. 395, station SW 3.

2 Station seven miles east of Leeds. This form of notation was used proviously and is used here to indicate the relative positions of the experimental stations with regard to the centre of Leeds. 
For the purposes of the crop tests about five tons of poor soilpractically subsoil-was taken from a small area in one of the fields at the Experimental Farm, Garforth, riddled, well mixed, and then used for filling seventy wooden boxes, each $1 \mathrm{sq}$. foot in cross-section and $I_{2} \frac{1}{2 t}$. deep. These were then distributed, ten boxes to each station and were there sunk in arable land and fenced round with wire netting.

The stations had been previously selected with a view to obtaining sites that were comparable in exposure, elevation, etc.-a task of no small difficulty, and so far as elevation is concerned, admitting of only very rough approximation, the extreme range being from about 200 feet (E 7) to $400 \mathrm{ft}$. (N 4). Further inequalities were met with in the nature of the subsoil in which the boxes were sunk, that at station $\mathrm{E} 4$ being the best, whilst at $\mathrm{E} 7, \mathrm{NE} 4$, NE 7 and SW 4 little fault could be found, but at $\mathrm{N} 4$ it was peaty and at $\mathrm{N} 7$ clayey. These differences undoubtedly affected the results.

On April 22 and 23, 1912, five boxes at each station were sown with perennial rye-grass $(0.3 \mathrm{gm}$. seed in each box) and the remaining five with barley, - the grass and barley boxes alternating in position. Both crops germinated well at all centres, and later on the barley was thinned out to 28 plants per box. Fair growth was made in all cases, and the barley was cut on Sept. 18 and the rye-grass on Oct. 4. It had become clear before this, however, that the results would be of little or no value for the purposes of the experiment, owing to the disturbing influence of two factors-the excessive wetness of the season and the varying degrees of shelter afforded by the surrounding crop in the field. Thus the crops at $N 5$ and $N 7$, which received the benefit of the cleanest atmosphere, were hampered continually by the waterlogged condition of the boxes: and on the other hand the crops in the dirty district, SW 4, benefited by abundant shelter provided by the adjacent crops, wheat and rhubarb.

Climatic irregularities we could not control, but shelter effects we endeavoured to eliminate for the following season by removing the boxes, during the winter of $1912-13$ to neighbouring pasture-fields at each centre. Here the boxes were sunk again, surrounded and covered over with wire-netting to keep out birds, rabbits, etc., and the whole further surrounded by a stout two-rail wooden fence to ward off grazing stock. Throughout the ensuing summer the grass inside these fences was periodically cut.

The rye-grass sown in the previous spring survived the winter satisfactorily and was allowed to grow on. The alternate five boxes which had previously grown barley were again sown with barley in 
April 1913, but owing to a sudden break in the weather before all the boxes had been sown the braird was so uneven that the plants had to be removed. It being then too late to re-sow barley, buckwheat was sown in these boxes on May 27 and 28-this crop having the reputation of being sensitive to smoke. Later the braird was thinned out leaving an equal number of plants in each box. Apart from weeding the boxes were not interfered with in any way until the crop was taken.

The season was in marked contrast to the preceding one, long spells of drought rendering the growth of the plants at times somewhat precarious, and leading eventually to the harvesting of the buckwheat a little prematurely on August 11 and 12.

Two cuttings of rye-grass were taken, the first on June 16 and 17 and the second on Oct. 27 and 28. At station NE 7 the rye-grass results were ruined by the persistent drifting of dead oak leaves from neighbouring trees into the boxes, causing the grass to be largely rotted out. For this reason the rye-grass results at this station have been discarded.

The results are summarised in the following tables:

Season 1913. Bucknoheat.

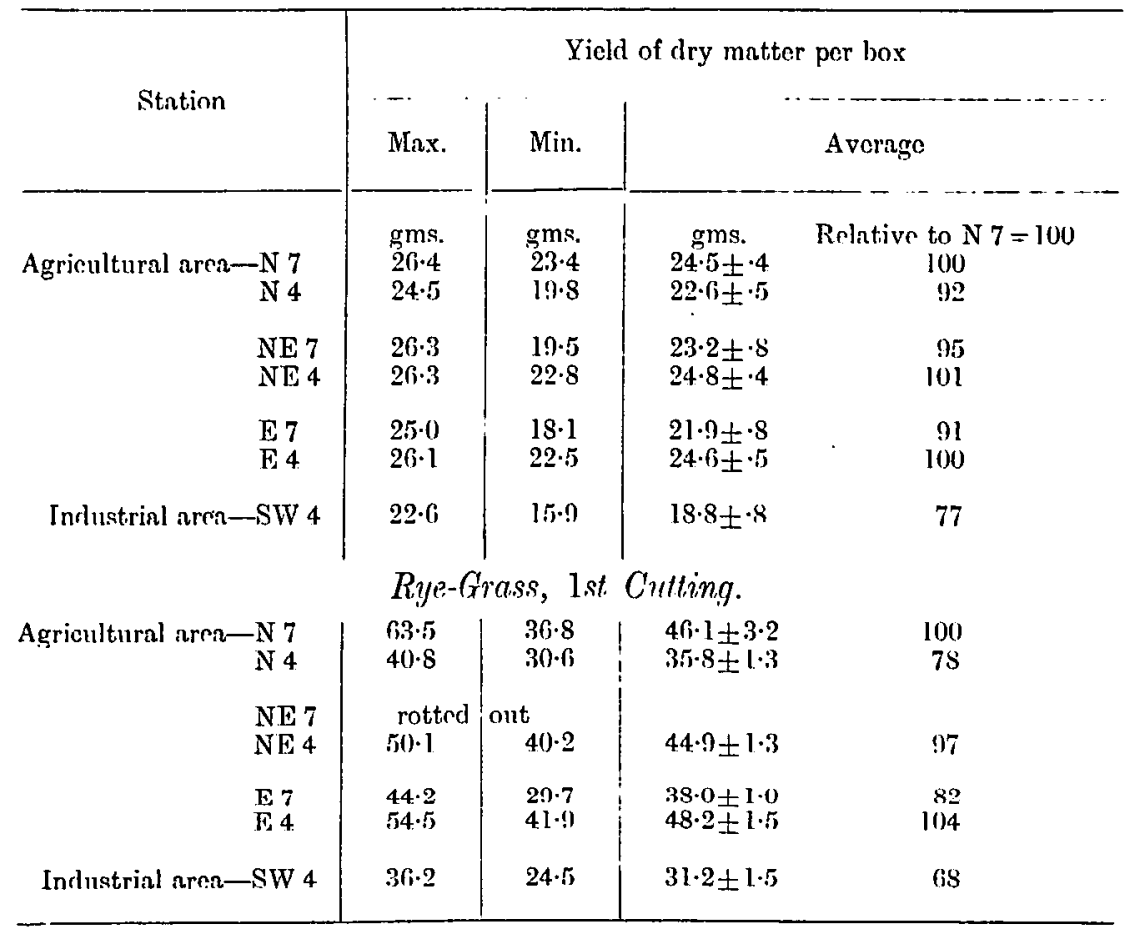


One cannot attach much importance to the results of a single season's trial, but as we find ourselves precluded from continuing the tests it is necessary to summarise here the general indications of the above results.

It may first be noted that, so far as the seven-mile stations are concerned, the crop results as they stand are in substantial agreement with the records of smoke pollution previously obtained in these districts, but the differences are little, if at all, outside the probable range of error.

At the four-mile stations, however, except for the marked inferiority of the results at the "dirty" station, SW 4, there is no evidence of differences parallel with those found in the rain records.

We are of opinion that the explanation of this discrepancy probably lies partly in the character of the soil in which the boxes were embedded, and partly in differences of elevation, aspect, wind-breaks, etc.

It has already been pointed out that station $\mathrm{E} 4$ was especially favourably situated as regards soil, but station N 4 was probably handicapped-although the site used in 1913 was much dryer than that used in the previous year. It is possible also that the proximity of peat to the boxes at this station in the earlier year may have established in the boxes detrimental conditions that were not eliminated during the following season.

In any case it was hardly to be expected that any sharply defined grading of the stations would be obtained in the course of one or two seasons.

When we come to the comparison of the crop obtained on the more polluted side of the city at station SW 4, with those obtained in the cleaner areas on the other side the difference is quite sharply defined. If we group together the results on the cleaner side we get the following comparison :

\begin{tabular}{|c|c|c|c|}
\hline & \multirow{2}{*}{ Buokwheat } & \multicolumn{2}{|c|}{ Ryc grass } \\
\hline & & 1st crop & 2nd crop \\
\hline $\begin{array}{l}\text { Clean districts } \\
\text { Dirty district }\end{array}$ & $\begin{array}{c}\text { gms. } \\
23 \cdot 6 \pm \cdot 3 \\
18 \cdot 8 \pm \cdot 8\end{array}$ & $\begin{array}{c}\text { gms. } \\
+2 \cdot 6 \pm 1 \cdot 0 \\
31 \cdot 2 \pm 1 \cdot 5\end{array}$ & $\begin{array}{l}\text { nuss. } \\
13 \cdot 0 \\
10 \cdot 8\end{array}$ \\
\hline $\begin{array}{l}\text { Diffcrence } \\
\text { Representing a nominal } \\
\text { loss of crop in the dirty } \\
\text { district of }\end{array}$ & $\begin{array}{l}4 \cdot 8 \pm \cdot 9 \\
20 \%\end{array}$ & $\begin{array}{c}11 \cdot 4 \pm 1 \cdot 8 \\
27 \%\end{array}$ & $21 \%$ \\
\hline
\end{tabular}


It would have increased the interest and value of the test if more centres on the polluted side of the city could have been included, but difficulties of supervision rendered this practically impossible. The station selected is typical, however, of very large areas of the West Riding that are being utilised for agriculture.

The crops at this centre were carefully examined at intervals for external signs of smoke damage, but beyond a slight reddening of the leaf-tips of the rye-grass no visible symptoms could be detected. At Garforth there were less marked effects on rye-grass and at several places also on buckwheat before cutting but this may have been due to drought. In passing it may be remarked that the season of 1913 was regarded by gardeners in and around Leeds as a particularly good one, so far as freedom from obvious smoke damage was concerned.

Buckwheat (Whole Plants).

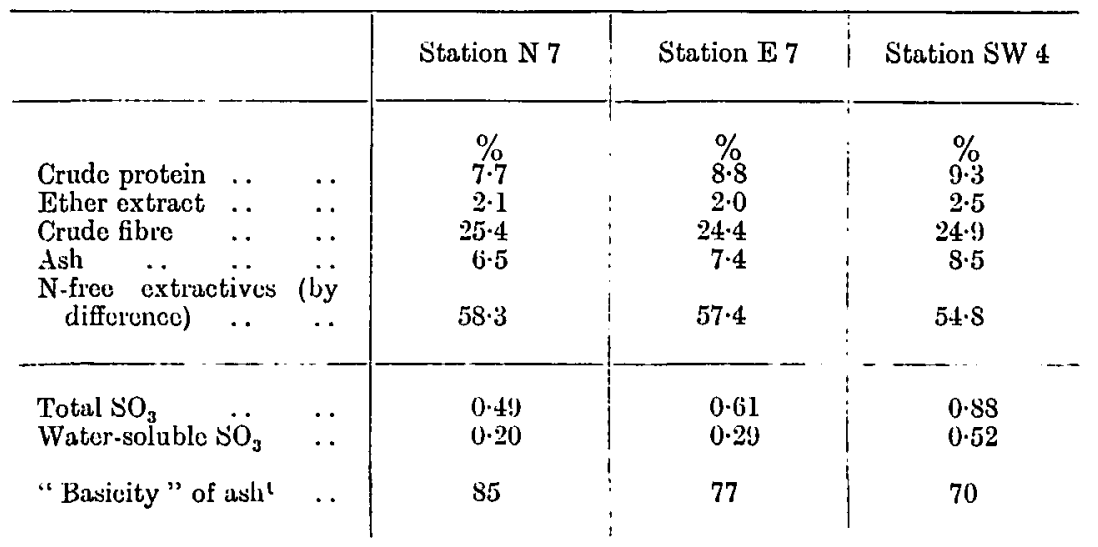

Rye-Grass, 1st Culting.

\begin{tabular}{|c|c|c|c|c|}
\hline $\begin{array}{ll}\text { Crudle protcin } & \\
\text { Ether extract } & . \\
\text { Crude fibre } & . \\
\text { Ash } & . . \\
\text { N.free extractives } \\
\text { difference) }\end{array}$ & $\begin{array}{c}. . \\
\ddot{.} \\
\ddot{0} \\
\text { (by } \\
. .\end{array}$ & $\begin{array}{r}5 \cdot 9 \\
2 \cdot 0 \\
3 \cdot \cdot 3 \\
6 \cdot 7 \\
52 \cdot 1\end{array}$ & $\begin{array}{r}6 \cdot 9 \\
2 \cdot 2 \\
34 \cdot 9 \\
7 \cdot 3 \\
48 \cdot 7\end{array}$ & $\begin{array}{r}(0 \cdot 4) \\
2 \cdot 0 \\
35 \cdot 5 \\
6 \cdot 9 \\
48 \cdot 7\end{array}$ \\
\hline $\begin{array}{l}\text { Total } \mathrm{SO}_{3} \\
\text { Water-soluble } \ddot{\mathrm{SO}}_{3}\end{array}$ & $\because$ & $\begin{array}{l}.94 \\
.60\end{array}$ & $\begin{array}{r}1 \cdot 05 \\
-59\end{array}$ & $\begin{array}{r}1 \cdot 40 \\
\cdot 60\end{array}$ \\
\hline Basicity of Ash' & .. & 15 & 12 & 11 \\
\hline
\end{tabular}

$1 \mathrm{Gms} . \mathrm{H}_{2} \mathrm{SO}_{4}$ required to neutralise $100 \mathrm{gms}$. ash. 
In previous experiments ${ }^{1}$ appreciable differences were found in the composition of Timothy grass grown on soils watered with neutral and acid rain-waters. For the purposes of comparison the crops grown in the present tests at three of the stations were analysed viz. at station N 7 (cleanest station), E 7 (intermediate in cleanliness) and SW 4 (dirtiest). The results are given on p. 400.

The results show no appreciable difference in the ingredients determinative of nutritive value, but the differences in sulphur-content which have been pointed out previously ${ }^{2}$ as characteristic of smoke-pollution are clearly defined. It will be noted further that the ash of the plants grown in the dirty district was distinctly more acid in character than in the case of the cleaner crops.

\section{Effects upon soil.}

After about two years' exposure in the boxes the soil at stations $\mathrm{N} 7$ and SW 3 was sampled for the purpose of determinations of lime-content and for bacteriological examination.

Calcium carbonate was estimated by Amos' method, with the following results :

$\begin{array}{clll}\text { Station N } 7 & \ldots & \ldots & 0.13 \% \\ , \quad \text { SW } 4 & \ldots & \ldots & 0.11 \%\end{array}$

The difference indicated cannot be regarded as outside the range of combined errors of sampling and analysis.

The samples of soil taken with the usual precautions for bacteriological examination were employed to ascertain the numbers of bacteria that would grow on agar plates of -5 acidity ${ }^{3}$.

Counts done in triplicate at the end of ten days' incubation at about $20^{\circ} \mathrm{C}$. gave the following results in millions per gm. of soil :

$$
\begin{array}{crrr}
\text { Station } & \text { N } 7 & 29 \cdot 4 \pm 1 \cdot 6 & \text { Difference } \\
, & \text { SW } 4 & 22 \cdot 9 \pm 3 \cdot 8 & 6 \cdot 5 \pm 4 \cdot 0 .
\end{array}
$$

A difference is indicated in favour of the cleaner district, but there is no great degree of certainty that it is not purely accidental. From the general appearance of the plates there could be little doubt as to the more vigorous growth obtained with the soil from $\mathrm{N} 7$.

1 Crowther and Ruston, loc. cil.

Crowther and Steuart, loc. cit.

3 i.e. in making the medium 5 c.c. of normal sodium carbonate solution were added to 1 litre of neutralised medium. 


\section{General Observations.}

The systematic observations of trees and gencral vegetation referred to in our earlier paper have been continued and extended.

The more striking features are summarised below :

Trees (1913).

In the earlier observations no general effect upon the opening of the buds of trees was detected, but closer observation has revealed that individual buds may be so badly injured that they either open quite late in the spring or not at all.

Leaves may be injured at any stage from the opening of the buds onwards, but they seem to be most susceptible when just expanding. If the leaves are jnjured for several seasons in succession the trees naturally get sickly and die off. First isolated twigs die, then the tops and branches, and finally the whole tree goes.

During May acute damage appeared on the leaves in the dirtier districts. For example, on May 8th near station SW 4 many of the young oak leaves peeping out from the buds were completely blackened, shrivelled up and dead. On a large open space (Woodhouse Moor) about a mile to the north of the centre of Leeds, sycamores attempted to produce new leaves throughout the season, but all were damaged severely so that little recovery was possible.

Towards the beginning of September in many parts of the town horse-chestnuts had only the ribs of their first set of leaves left, but these had been augmented by a complete set of new green leaves.

In woods three miles to the south (Middleton) the smoke blew through practically unchecked during May and considerable damage was done. As the wood got covered in with foliage little fresh damage had been done by July 11th. Elders which were previously blackened and unsightly had made apparently a complete recovery; only when the branches were pushed aside could signs of the damaged shoots be discovered. Young oaks had not made a good recovery and the old damage was still evident; the red patches of dead leaf-tissue had fallen away leaving fresh green laminae full of holes; where the opening buds had been destroyed completely the twigs were still bare. The same was the case with the damaged leaves of other trees.

Conifers are more susceptible than deciduous trees, and in general trees, particularly when isolated, more so than most farm crops. 


\section{Farming.}

In the smoky districts farmers complain that they have to "apply heavier tillage" to get good results. It is quite common to apply 30 tons of dung to the root crop. Heavier feeding of stock is necessary, and even then the results may be unsatisfactory $\mathbf{l}^{\mathbf{1}}$ Hedges are bad and expensive to replace. Wire fencings last one-half or one-third of the time they ought to. Galvanised netting lasts only four or five years. Corrugated iron roofing on sheds has also a very short life. In the pastures" the "finer grasses die out and they become coarse and distasteful to stock." In extreme cases the grass dies out in patches in which only sorrel will live, and applications of lime are then found greatly to improve matters. In some cases clovers, specially red clover, die out during the winter and the farmers are consequently leaving clovers out of their one-year leys and sowing only rye-grass.

An attempt was made to find out which grasses do best in smoky districts by examining meadows while the grasses were in flower. Cocksfoot, rye-grass, fescue grasses and meadow foxtail do quite well, and all the commonly sown meadow grasses. Too often weeds and soft brome grass predominated. Large clumps were often filled with Holcus or Agrostis, and sweet vernal occupied too much space in the poorer meadows. Red clover seemed quite common. The coarseness of the pastures may be due to the animals not caring to eat them close.

The young leaves of cereals may turn red at the points and possibly may bleach. The shoots are thinned out, the crop ripens unevenly, empty or half-filled ears occur and the pickles do not swell properly. Serious damage of this character, however, is limited to the near neighbourhood of coke ovens, forges, etc. All over the dirtier districts the grain is a dirty bleached grey colour and sells badly when exposed for sale in the market beside clean samples. A farmer may easily lose $£ 1$ per acre of white crop by this means alone. Red wheats show up the dirt less than white and are consequently favoured; black winter oats and "Tartar Kings" are the favourite varieties of oats on the farms in the dirtiest areas. Good malting barley cannot be grown.

The following are the results of some examinations of grain. Samples were obtained from farms on which obvious smoke damage was known to occur. They are compared with average samples, and show a considerable falling off in the pickle weight. The $\mathrm{SO}_{3}$ figures were

1 See Steuart, Journal of the Board of Agriculture, Jan. 1914, p. 897.

"Cf. Webster's "Town Planting," pp. 6 and 171. 
obtained as follows: 25 gms. of grain were washed with small successive portions, amounting to 250 c.c. of distilled water. The washings were boiled with bromine water, evaporated down, and the sulphate precipitated in the usual way.

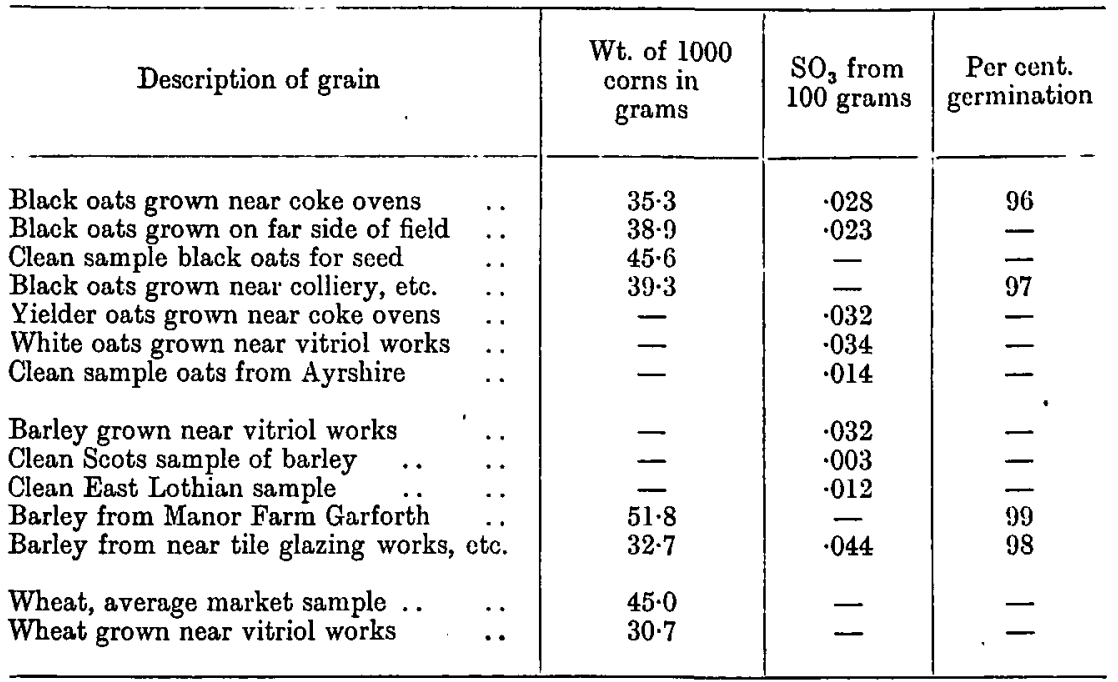

Farmers and gardeners have often great difficulty in obtaining compensation for smoke and fume damage, particularly where the source of the noxious gases is complex. Acute smoke injury on farms is restricted in its range and it is rarely found that a number of crops grown successively in a given locality show this effect. The detrimental action of smoke is found at its maximum in damp weather under atmospheric conditions that cause an accumulation and concentration of the smoke gases over the growing crops. A farmer seldom can complain of a total loss of crop and it is this element of partial loss varying from year to year which makes the diagnosis of smoke damage and its assessment for purposes of compensation so hard to decide. In any case monetary compensation is little satisfaction to a real farmer. Hence many of the more enterprising farmers refuse to farm in smoke infested districts, while in other cases the men get very discouraged.

Gardeners with experience in clean districts state that "everything seems to stand still." Quick growing plants and plants with thick leaves seem to stand the smoke best. Smoke dirties everything. With cauliflowers and broccoli the practice is to break one or two leaves over the developing flower to keep off the dirt. A common complaint is that fruit trees and bushes do not thrive or bear well. In the worst 
districts rhubarb for forcing is practically the only market crop grown in the open. "Winter onions, cabbage and lettuce have failed me so often that I have ceased to grow them ; - before the smoke was so bad crops used to stand the winter." This is a more or less general experience in smoky districts. Summer cabbages may be grown with fair success, while those sown in July and planted out in September die off during the winter. A similar effect is commonly experienced with young flower seedlings ${ }^{1}$.

It is difficult to prepare a good lawn in some parts of the town as the finer grasses die out. The soil requires special preparation and dusting with chalk. Seed mixtures are consequently sold containing considerable quantities of agrostis, perennial rye-grass and even timothy.

In some parts roses have been tried over and over again but in a year or two nothing of them remains. Each gardener in a polluted district knows fairly well what varieties he can most safely propagate and he has to stick rigidly to these, without much choice in some cases. Thus in a cemetery garden on the more polluted side of Leeds mainly stocks and violas were relied on for a show of flowers and the violas died off during the winter. Slips for their propagation had to be obtained from a clean district.

These are some of the difficulties that beset the agriculturist and horticulturist in the neighbourhood of the large industrial city. But for smoke they might reap far greater benefit from the proximity of large bodies of consumers. We had hoped to continue our investigations until we could arrive at a reliable assessment of the material loss that is inflicted upon the farmer and gardener over thousands of acres of this country by the distribution of excessive smoke from the towns, but must rest content to have obtained sufficient preliminary evidence to warrant a further extension of the investigations when circumstances permit.

In conclusion we would express our indebtedness to a great number of farmers, gardeners and others who have assisted us in various ways and especially to those who have kindly given us facilities for our crop tests in their fields.

Further we would not omit to record our appreciation of the support accorded to us by the Board of Agriculture and Fisheries, out of the research funds at their disposal, without which the extension of our investigations into the rural areas would have been quite impossible.

1 Compare this vol., p. 391. 